\title{
Accounting
}

\section{The effects of financial factors on Peruvian mining companies share price}

\author{
Almendra Carhuamaca-Flores ${ }^{a^{*},}$ Vania Malena Almonacid-Carranza ${ }^{a}$, Nivardo Alonzo Santillan- \\ Zapata $^{a}$, Pedro Bernabe Venegas-Rodriguez ${ }^{\text {a }}$ and Jimmy Alberth Deza-Quispe ${ }^{a}$
}

\author{
${ }^{a}$ Universidad Continental, Perú

\begin{tabular}{l} 
C H R O N I C L E \\
\hline Article history: \\
Received: August 23, 2020 \\
Received in revised format: \\
October 302020 \\
Accepted: November 14, 2020 \\
Available online: \\
November 14, 2020 \\
\hline Keywords: \\
Common voting share \\
Financial factors \\
Share prices \\
Copper mining companies
\end{tabular}

\section{A B S T R A C T}

This research analyses the relationship and relative importance of financial factors on the Peruvian mining copper companies' share prices from 2010 to 2018. Voting common share prices were focused and book value, dividend per share, dividend yield, price earnings, earnings per share and roe were employed as regressors. Fixed-effects regression was used, and tests of stationarity, distribution, and specification harnessed. It was found that earnings per share and dividend yield had a positive and significant relationship with share prices, while book value had a negative one.

(C) 2021 by the authors; licensee Growing Science, Canada

\section{Introduction}

Since the end of the $19^{\text {th }}$ century, because of the expansion of electricity, demand for copper demand has been increasing over time (Romero \& Contreras, 2006). Such phenomenon happened because of copper properties for the manufacture of electrical cables, motors, radiators among others necessary for our modern day (Del Águila, Martínez, \& Regalado, 2017). Therefore, the global demand for copper has tripled since 1970 and it continues growing (International Council on Mining \& Metals, 2011). Hence, an interdependent relationship between nations exists. For one side, the nations that transform copper into consumer goods; and on the other side, the countries where this raw material is extracted ( $\mathrm{PwC} 2019)$.

Peru ranks in this global supply chain as the world's second-largest supplier of copper (Fundación Chile 2018). Also, current investment amount in mining copper projects has reached up to 6 billion of dollars, favored for the Peruvian friendly foreign investment environment (Cámara de Comercio de Lima 2019). Nowadays, there are 25 copper mining projects out of 59 total mining projects valued at more than $\$ 53$ billion (Cámara de Comercio de Lima 2019). It is necessary to add that copper is the country's main exportation, then representing more than $25 \%$ of country foreign trading (Ministerio de Energia y Minas 2019). The importance of copper in the economy is reflected in the in the Peruvian stock market since copper mining companies shares represent about $20.26 \%$ of the total number of operations in capital shares; and $21.68 \%$ of total traded capital shares in the Peruvian Stock Market (Bolsa de Valores de Lima 2018).

* Corresponding author

E-mail address: 75196191@continental.edu.pe (A. Carhuamaca-Flores) 
For shareholders, it is important to get as maximum profit as possible thorough getting dividends or selling their participations (Becket 2017). Then it is necessary for them to understand what factors seem to affect share prices behavior (Mahapatra and Biswasroy 2011). Therefore, this research will be focused on analyzing financial factors with the capability of influencing the market price of copper mining companies' voting shares indexed in the Lima Stock Exchange from 2010 to 2018. Variables were selected by following the recommendations of similar studies.

\section{Literature review}

Analysis of financial factors affecting the market price of shares have been carried around the world in different markets. In the Brazilian stock market Vázquez and Miranda (2019) analyzed the relationship between economic performance indicators and the share price of Brazilian companies by employing structural equation modeling. Return on equity [i.e. ROE], asset rotation, gross margin, indebtedness, liquidity, and current assets were employed as explaining variables. Periods analyzed were 20012007 and 2010-2016. Researchers found a positive and significant relationship between return on equity [ROE] and the share price for both periods while such relationship happened in the second period for gross profit.

Also, Sharif et al. (2015) analyzed the factors affecting share prices of companies listed in the Bahrain Stock Market from 2006 to 2010. By employing Ordinary Least Square Regression [OLS], fixed effects and random effects model researches identified that return on equity, book value per share, dividend per share, price earnings and firm size had a significant and positive relationship with share prices; while dividend yield was found to have a negative but significant one.

Kembaren, Achsani and Maulana (2019) analyzed the impact of dividend per share, non-performing loan, net interest margin, inflation rate and interest rate on the share prices of Indonesian Commercial Banks from 2013 to 2017. By employing OLS regressions it was found that dividend per share and net interest margin had a positive and significant relationship with stock price.

Ozlen (2014) examined the effects of total assets turnover ratio, debt ratio, current ratio, price to earnings, net profit margin and book value on stock values from 2000 to 2012 in electric, food, communication, paper, chemistry, metal-product, metal-main, stone, textiles, commerce and transportation companies indexed in the Turkish stock market. In all sectors, the researcher found that book value had a positive and significant effect. Total assets variable was found to be positive and significant for metalproduct, stone, commerce, and transportation sectors, but negative and significant for the textile sector. Debt had a positive and significant relationship for food and transportation sector; while negative and significant for metal-product and textile companies. Current ratio was found to be positive and significant for electric, metal-product and textiles enterprise while negative for metal-main and transportation companies. Net profit had a negative and significant relationship only in the transportation sector. Finally, price to earnings ratio was found to be positive and significant for stone and textile companies while negative for communication sector. Duy et al. (2017) analyzed the factors that affect the price of shares corresponding to industrial companies listed in the Stock Exchange in Vietnam. Data analyzed belonged to the period 2012 to 2015. The research found that earning per share had a positive but non-significant relationship with share prices. Ligocká \& Stavárek (2019) studied the effects of acid ratio, current ratio, net working capital, return on assets [i.e. ROA], ROE, return on capital employed [i.e. ROCE], debt ratio, equity ratio and financial leverage on Austrian, Polish and Swiss food firms stock prices. By employing Generalized Method of Moments regression, researchers found that in Austrian companies ROA had a negative and significant relationship with the share price, while for Polish and Swiss firms such relationship was positive. Also, they found that ROE had a negative and significant relationship with the dependent variable only in Austrian market, while a positive in Polish and Swiss markets. However, only in the Polish market that relationship was positive. Moreover, Tambuati et al. (2017) studied the effects of price earnings, ROA and systematically risk among other external factors on Indonesia companies stock prices from 2008 to 2015. They found that price earnings and ROA had a positive and significant relationship on stock prices. Hanifah (2019) explored the effects of earnings per share, price earnings and price book value on stock price of telecommunication companies indexed in the Indonesian Islamic Stock Index. The period studied was from 2013 to 2017. The research found that only price book value had a positive and significant effect on stock prices.

\subsection{Financial factors}

Financial factors are indicators of every company. Hence, data were obtained from audited financial reports openly available in the Sociedad de Mercado y Valores database. It is necessary to add that for companies listed in the Lima Stock Exchange, their financial statements must be available (Congreso de la República del Perú 2011). Due to literature review, variables selected were book value per share, dividend per share, price earnings, earnings per share and ROE, as shown in Table 2.

\subsubsection{Earnings per share}

This ratio is the coefficient between net profit and the number of shares issued by the entity (Sherman 2015). Then this ratio has two main components. One is the net income which is the after tax earnings for the company. Jaramillo (2010) states that profitability is company's main objective. Furthermore, profits serve as a benchmark for the decision to pay off dividends to the 
shareholders (Sherman 2015). In the other side, the other component is the number of available shares; hence, treasury stock was not taken into consideration.

\subsubsection{Dividend per share}

This ratio is obtained by dividing the total dividends paid to the shareholders and the number of shares issued (Asadi 2013). Dividend payment decision is taken by the shareholders meeting, which is composed of voting shareholders (Sherman 2015). In the current study, only paid dividends [not declared] were taken into consideration. It is necessary to add that the availability of net income does not mean a mandatory dividend payment since the shareholders meeting can reinvest it.

\subsubsection{Book Value}

This ratio is the amount of capital divided by the issued shares of companies (Sherman 2015). In Peru, the Ley General de Sociedades (1998), which is the companies ruling bill, commands that this information must be exhibited in the companies' financial results. Also, the bill establishes that under certain conditions issued shares may change. Book value information is available in every company financial statement.

\subsubsection{Dividend Yield}

It is the coefficient between dividend per share and price per share (Sharif, Purohit, and Pillai 2015). According to Sherman (2015) this is the "measure of the return to common stockholders through dividends" (p. 51). Hence, it focuses on the returns provided by dividend payments only.

\subsubsection{Price earnings}

According to Sherman (2015) price earnings ratio is "of primary concern to financial investors" (p. 50); moreover, he adds that " it can be interpreted as the value that investors in the stock market place on every dollar of earnings for a particular firm" (p. 50). This ratio is obtained by dividing the market price of the share and the earnings per share ratio.

\subsubsection{Return over equity}

Return over equity also known as ROE, measures the financial company performance over its capital. Then, ROE gives information over capital profitability (Sherman 2015). The way this ratio is obtained is by dividing net income over equity.

\subsubsection{Peruvian Stock Market}

The Peruvian stock market is being ruled since 2011 by the Superintendencia de Mercado y Seguros - hereinafter SMV (Congreso de la República del Perú 2011). The Peruvian stock market takes place in the Lima Stock Exchange or $B V L$ which is represented by the $S \& P / B V L$ Peru General Index. All companies are required by law to have an open access policy regarding their financial statements (Congreso de la República del Perú 2011). Also, the Ley General de Sociedades (1998) orders that all companies indexed in the $B L V$ should be set up as an open society. That law allows indexed companies in the $B V L$ to have 3 kinds of shares: common shares with voting rights, common shares without voting rights [also called preferential ones] and investment shares. Every bearer of any kind of shares has the right to receive dividends; however, such right varies substantially from every kind of share. Also, there are differences related to political rights and preferences. Since the study is focused on common voting shares, information related to other kind of shares is not deeply provided.

\subsubsection{Common shares with voting rights}

This kind of share provides investors political rights over the entity. According to the Ley General de Sociedades (1998) these rights are the active participation in the shareholders' meetings, approve the economic performance stated in the financial results, decide on the use of profits, elect and fire directors, request audits, select the audit entity, modify the business status, alienate assets, and participate in the decision of transforming, reorganizing, merging and even dissolving the company.

\subsection{Theoretical Framework}

\subsubsection{Fixed effects regression}

This regression catches the changes over time. It is represented as follows:

$$
\mathrm{Y}_{\mathrm{it}}=\beta_{1} \mathrm{X}_{\mathrm{it}}+\alpha_{\mathrm{I}}+\mathrm{u}_{\mathrm{it}}
$$

$Y_{i t}$ represents the dependent variable, $\beta_{1}$ the coefficients of each independent variable, i.e. $X_{i t} ; \propto_{i}$ are the contrasts between objects according to Mason (2001), Wooldridge () call them unobserved effects. $u_{i t}$ is the idiosyncratic error. Moreover, according to Wooldrige (2010) fixed effects allows arbitrary correlations among the observed and unobserved variables, hence 
not allowing time-invariant variables. It differs with random effects regressions. Also, this regression absorbs $\propto_{i}$; therefore, this regression asks for certain condition that enables robust and unbiased results (Wooldrige 2010). The first condition is $E\left(u_{i t} \mid x_{i}, c_{i}\right)=0, t=1,2, \ldots T$. Then, it requires exogeneity between $u_{i t}$, and $x_{i}, c_{i}$. Second, $\operatorname{rank}\left[\sum_{t=1}^{T} E\left(\ddot{x}_{i t}^{\prime} \ddot{x}_{i t}^{\prime}\right)\right]=$ $\operatorname{rank}\left[E\left(\ddot{X}_{i}^{\prime} \ddot{X}_{i}{ }_{i}\right)\right]=K$. It forbids time-invariant variables but allowing dummy variables if these time-invariant variables are interacting with time-variant variables. Finally, $E\left(u_{i} u_{i}^{\prime} \mid x_{i}, c_{i}\right)=\sigma_{u}^{2} I_{T}$. Hence, errors, $u_{i t}$, have a constant variance over time and should not correlated with neither observed variables nor unobserved variables.

\subsubsection{Data}

Data was obtained through the audited financial statements of copper mining companies listed in the Lima Stock Exchange. As stated before this date is openly availabe in SMV webpage. Data collected is from 2010 to 2018. Table 1 presents the coding of the selected companies.

Table 1

Analyzed voting shares

\begin{tabular}{lllllll}
\hline Voting shares & BUENAVC1 & MILPOC1 & ATACOAC1 & CVERDEC1 & MINCORC1 & BROCALC1 \\
\hline
\end{tabular}

\section{Methodology}

This research employed a descriptive, quantitative, and longitudinal methodology to analyze internal factors with the capability of affecting copper mining companies voting shares price for the period 2010-2018. All statistical analyses employed STATA econometric and statistical software. Variables selected were book value, dividend per share, dividend yield, price earnings, earnings per share and roe. Next, variables were evaluated to ensure the assumption of stationary behavior as suggested by Baumöhl \& Lyócsa (2009). Hence, Levin Lin and Chu's tests were employed since the panel was balanced. The number of lags was proposed by the software in the Levin Lin and Chu test. Only, the price earnings variable was not stationary at level, then it was necessary to employ its first difference. Fonti (2017) states that data distribution is a precondition for results validity of parametric analysis. Therefore, data distribution was tested by Galvao et al (2013) test, which analyzes the asymmetry and kurtosis of sigma_u [between groups] and sigma_e [erors] residuals. It analyzes them individually and jointly using the bootstrap technique suitable for panel-type data (Alejo et al. 2015). Therefore, data set proved to have a normal distribution. According to theory fixed effects regression was the most suitable because all variables were time-variant. Models specification was evaluated by employing the Fourier Regression Specification Error - Test - Linear transformation [hereinafter, FRESETL] test in order to avoid erroneous specifications because of omitted variables (DeBenedictis and Giles 1998). Moreover, for avoiding potential heteroscedasticity issues, robust standard errors values were employed in the research as suggested by Croux, Dhaene and Hoorelbeke (2003) and Stock and Watson (2008). Finally, results discussion was performed, and conclusions provided.

\section{Results}

\subsection{Variables employed}

Table 2

Initial variables

\begin{tabular}{ll}
\hline Dependent variable & Microeconomics variables \\
\hline Voting share prices & Book value, Dividend per share, Dividend yield, Price earnings, Earnings per share, Return over assets \\
\hline
\end{tabular}

Therefore, the regression models were expressed as follows:

Model 1

vsstkp $_{\text {it }}=\beta 1$ bvs $_{\text {it }}+\beta 2$ dps, $_{\text {it }}+\beta 3$ divyield $_{\text {it }}+\beta 4$ pearnings, $_{\text {it }}+\beta 5$ eps $_{\text {it }}+\beta 6$ roe $_{\text {it }}+\alpha_{\text {it }}+\mu_{\text {it }}$

Table 3

Levin Lin and Chu test

\begin{tabular}{|c|c|c|c|}
\hline Variable & Unadjusted t & Ajusted $t$ & p-value \\
\hline \multicolumn{4}{|l|}{ Model 1} \\
\hline Voting share price & -7.513 & -5.748 & 0.000 \\
\hline Book value & -6.780 & -4.666 & 0.000 \\
\hline Dividend per share & -6.528 & -1.995 & 0.023 \\
\hline Dividend yield & -8.075 & -6.069 & 0.000 \\
\hline Price earnings* & -7.484 & -5.170 & 0.000 \\
\hline Earnings per share & -4.651 & -2.905 & 0.002 \\
\hline ROE & -7.162 & -5.491 & 0.000 \\
\hline
\end{tabular}

*at first difference 
Both dependent and microeconomic variables follow stationary behavior. It was necessary to take the first difference only for the variable price earnings showed in Table 3 . Therefore, since all variables are stationary spurious results were avoided as recommended by Baumöhl \& Lyócsa (2009).

Table 4

Distribution test

\begin{tabular}{|c|c|c|c|c|c|c|c|}
\hline & Coefficient & Standard error & $\mathrm{z}$ & $\mathrm{p}>|\mathrm{z}|$ & Confidence Intervals $95 \%$ & Joint test & $\mathrm{p}>\operatorname{chi} 2$ \\
\hline \multicolumn{8}{|l|}{ Model 1} \\
\hline Skewness_e & 0.871 & 0.495 & 1.760 & 0.078 & -0.098 & 3.98 & 0.1365 \\
\hline Kurtosis_e & 1.950 & 2.081 & 0.940 & 0.349 & -2.128 & & \\
\hline Skewness_u & 6.709 & 14.284 & 0.470 & 0.639 & 34.705 & 1.54 & 0.4633 \\
\hline Kurtosis_u & 73.679 & 64.172 & 1.150 & 0.251 & -52.095 & & \\
\hline
\end{tabular}

According to Table 4, distribution tests show that jointly skewness and kurtosis residues of both error and variance are normally distributed since $p>.05$. Hence, normal distribution assumption is fulfilled.

Table 5

Specification test

\begin{tabular}{lll}
\hline Test & Value & $\mathrm{p}$ \\
\hline FRESETL 1 & 0.521 & 0.598 \\
FRESETL 2 & 2.239 & 0.083 \\
FRESETL 3 & 1.986 & 0.093 \\
\hline
\end{tabular}

FRESETL tests reject the alternative hypothesis of misspecification, as is shown in Table 5. Therefore, there is evidence that the model is correctly specified. Consequently, the results probably are not biased nor imprecise.

\subsection{Descriptive statistics}

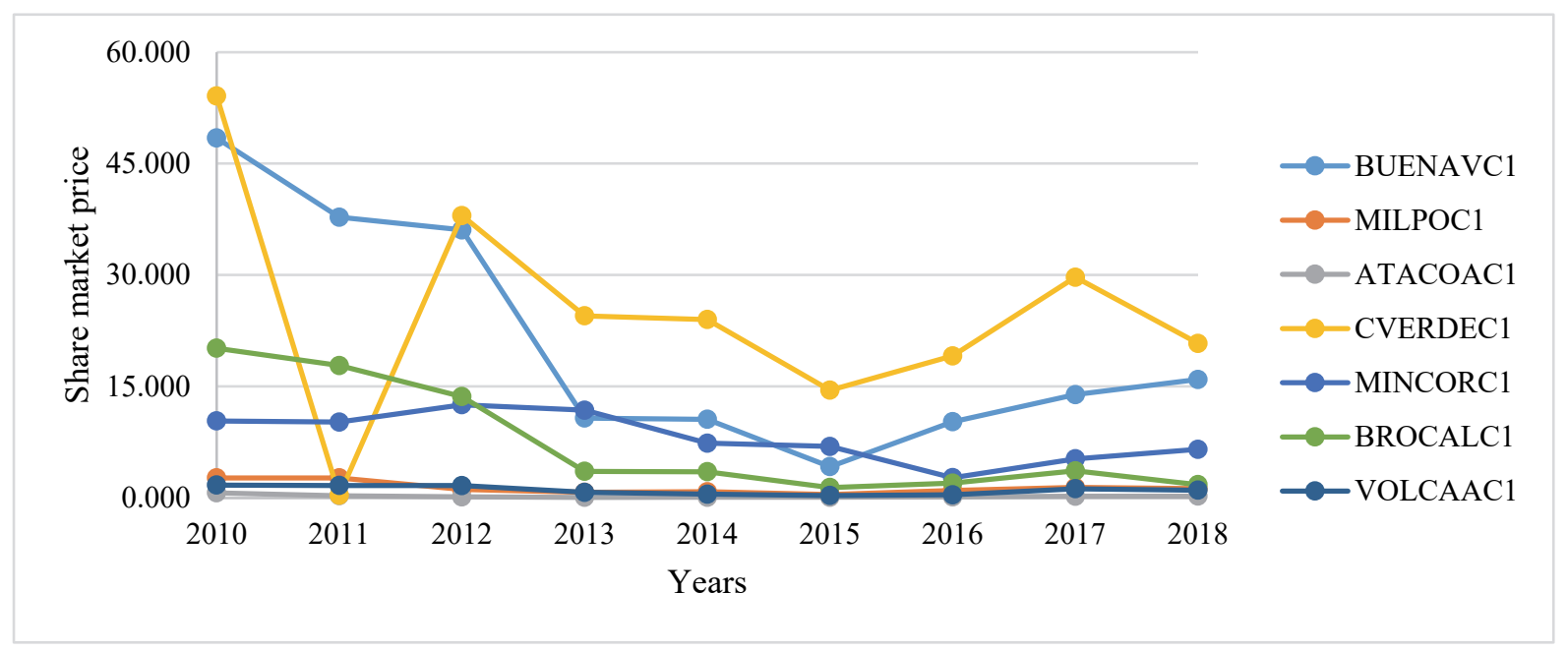

Fig. 1. Share prices evolution from 2010 to 2018 (Source: Sociedad de Mercado y Valores)

Fig. 1 shows that CVERDEC1 had a big drop in 2011, and its price has suffered both growing and decreasing periods. However, CVERDEC1 had the biggest share price value in 2018. In the case of BUENAVC1, its value fell until 2015 and has been recovering since then. BROCALC1 value has been falling since 2010, and it seems that still cannot recover its previous values. MILPOC1, ATACOAC1 and VOLCAAC1 values did not have big changes in its values. According to Table 6, share price average values decreased until 2015, and had a growing period until 2017. Its median values had a high reduction in 2018. Also, its maximum values were decreasing until 2015, and growing until 2017 as its standard deviation. Book value average and median values increased from 2015 to 2017. Also, since 2012 its maximum and minimum values were decreasing until 2015, grew in 2016 and 2017, and fell again in 2018. Its standard deviation values had mixed trends with a growing period followed by a decreasing one. Dividend per share average values had a continuous decreasing until 2016, and since then it was growing. Its median values fell from 2010 to 2015 , when reached its lowest value due to the fact the majority of companies did not pay dividends. However, since 2015 such value has been increasing. Furthermore, its maximum numbers were falling until 2016. Its minimum values remained the same for all the periods analyzed then it is possible to claim that there was at least one company that did not pay dividends in all the studied years. Dividend yield average values reached its lowest level in 2016. Like in dividend per share, dividend yield had its lowest value in 2015. Furthermore, maximum values were reached in 2011 and 2017 while in all the year analyzed there was at least one company that did not pay dividends. Price earnings average values were 
increasing until 2016 and its values have been slightly falling since then. A similar behavior is seen in its median values. Moreover, its maximum values were increasing until 2015. The lowest value happened in 2010, and it was increasing with some falls since then. In the case of its standard deviation it did not have huge changes. Earnings per share average values decreased until 2012, in the following years it increased its value but had a deep fall in 2015. Also, its median values had huge decreasing in 2015. Its maximum values were decreasing until 2015; while its minimum values had both increasing and decreasing periods. ROE average values could not recover its initial values; also, it had its lowest value in 2015 as the median. The maximum roe value was recorded in 2011; while the lowest one in 2015. Also, roe minimum vales remained negative from 2012 to 2016.

Table 6

Descriptive statistics

\begin{tabular}{|c|c|c|c|c|c|c|c|c|c|c|}
\hline \multirow[t]{2}{*}{ Variable } & \multirow[t]{2}{*}{ Measure } & & \multicolumn{8}{|c|}{ Year } \\
\hline & & 2010 & 2011 & 2012 & 2013 & 2014 & 2015 & 2016 & 2017 & 2018 \\
\hline \multirow[t]{5}{*}{ Share price } & Mean & 15.582 & 8.075 & 11.746 & 6.033 & 5.398 & 3.213 & 4.250 & 6.516 & 5.587 \\
\hline & Median & 2.710 & 1.670 & 1.663 & 1.195 & 0.871 & 0.704 & 1.999 & 2.779 & 1.790 \\
\hline & Max & 54.100 & 37.780 & 38.000 & 24.500 & 24.000 & 14.500 & 19.110 & 29.700 & 20.800 \\
\hline & Min & 0.445 & 0.301 & 0.149 & 0.075 & 0.094 & 0.084 & 0.140 & 0.225 & 0.238 \\
\hline & Standard deviation & 21.256 & 12.619 & 15.221 & 8.244 & 7.864 & 4.821 & 6.371 & 9.654 & 7.578 \\
\hline \multirow{5}{*}{$\begin{array}{l}\text { Book value per } \\
\text { share }\end{array}$} & Mean & 0.920 & 0.742 & 1.055 & 1.216 & 1.158 & 1.053 & 1.061 & 1.088 & 1.049 \\
\hline & Median & 0.356 & 0.371 & 0.392 & 0.358 & 0.335 & 0.294 & 0.298 & 0.309 & 0.297 \\
\hline & $\operatorname{Max}$ & 2.958 & 3.711 & 3.923 & 3.579 & 3.349 & 2.935 & 2.983 & 3.088 & 2.974 \\
\hline & Min & 0.356 & 0.371 & 0.392 & 0.236 & 0.221 & 0.194 & 0.197 & 0.204 & 0.110 \\
\hline & Standard deviation & 1.119 & 1.113 & 1.344 & 1.346 & 1.288 & 1.190 & 1.204 & 1.228 & 1.210 \\
\hline \multirow[t]{5}{*}{ DPS } & Mean & 0.540 & 0.330 & 0.213 & 0.244 & 0.137 & 0.023 & 0.024 & 0.117 & 0.142 \\
\hline & Median & 0.073 & 0.051 & 0.030 & 0.030 & 0.012 & 0.000 & 0.004 & 0.008 & 0.038 \\
\hline & Max & 2.714 & 1.907 & 0.860 & 1.322 & 1.089 & 0.136 & 0.093 & 0.513 & 0.571 \\
\hline & Min & 0.000 & 0.000 & 0.000 & 0.000 & 0.000 & 0.000 & 0.000 & 0.000 & 0.000 \\
\hline & Standard deviation & 0.904 & 0.621 & 0.315 & 0.427 & 0.358 & 0.045 & 0.036 & 0.177 & 0.214 \\
\hline \multirow[t]{5}{*}{ Dividend yield } & Mean & 0.029 & 0.036 & 0.024 & 0.048 & 0.033 & 0.016 & 0.011 & 0.040 & 0.027 \\
\hline & Median & 0.018 & 0.019 & 0.017 & 0.031 & 0.003 & 0.000 & 0.003 & 0.006 & 0.006 \\
\hline & $\operatorname{Max}$ & 0.116 & 0.187 & 0.089 & 0.135 & 0.148 & 0.067 & 0.046 & 0.185 & 0.076 \\
\hline & Min & 0.000 & 0.000 & 0.000 & 0.000 & 0.000 & 0.000 & 0.000 & 0.000 & 0.000 \\
\hline & Standard deviation & 0.037 & 0.059 & 0.032 & 0.052 & 0.052 & 0.024 & 0.016 & 0.065 & 0.032 \\
\hline \multirow[t]{5}{*}{ Price earnings } & Mean & 0.300 & 0.305 & 0.319 & 0.356 & 0.383 & 0.440 & 0.430 & 0.392 & 0.367 \\
\hline & Median & 0.321 & 0.321 & 0.368 & 0.432 & 0.443 & 0.492 & 0.462 & 0.460 & 0.410 \\
\hline & Max & 0.436 & 0.475 & 0.485 & 0.503 & 0.559 & 0.575 & 0.559 & 0.528 & 0.503 \\
\hline & Min & 0.084 & 0.087 & 0.076 & 0.078 & 0.078 & 0.140 & 0.189 & 0.070 & 0.171 \\
\hline & Standard deviation & 0.121 & 0.140 & 0.152 & 0.173 & 0.170 & 0.144 & 0.128 & 0.161 & 0.112 \\
\hline \multirow[t]{5}{*}{ Eps } & Mean & 1.115 & 1.046 & 0.935 & 0.214 & 0.256 & -0.228 & 0.014 & 0.382 & 0.244 \\
\hline & Median & 0.651 & 0.708 & 0.222 & 0.059 & 0.057 & -0.024 & 0.030 & 0.162 & 0.039 \\
\hline & $\operatorname{Max}$ & 3.012 & 3.081 & 2.544 & 1.752 & 1.079 & 0.209 & 0.974 & 1.157 & 1.282 \\
\hline & Min & 0.024 & 0.014 & -0.009 & -0.464 & -0.299 & -1.248 & -1.274 & 0.011 & -0.053 \\
\hline & Standard deviation & 1.243 & 1.141 & 1.126 & 0.750 & 0.499 & 0.516 & 0.689 & 0.484 & 0.476 \\
\hline \multirow[t]{5}{*}{ ROE } & Mean & 0.352 & 0.332 & 0.216 & 0.061 & 0.123 & -0.112 & 0.056 & 0.168 & 0.081 \\
\hline & Median & 0.254 & 0.247 & 0.186 & 0.101 & 0.041 & -0.100 & 0.070 & 0.103 & 0.015 \\
\hline & Max & 0.680 & 0.914 & 0.736 & 0.285 & 0.603 & 0.145 & 0.259 & 0.465 & 0.385 \\
\hline & Min & 0.162 & 0.125 & -0.083 & -0.166 & -0.028 & -0.386 & -0.115 & 0.021 & -0.031 \\
\hline & Standard deviation & 0.219 & 0.272 & 0.266 & 0.148 & 0.222 & 0.209 & 0.130 & 0.169 & 0.149 \\
\hline
\end{tabular}

\subsection{Regression analysis}

Table 7

Model 1 regression analysis

\begin{tabular}{|c|c|c|c|c|c|c|c|c|}
\hline Votings share & Coefficient & Robust Standard Error & $\mathrm{T}$ & $\mathrm{P}>\mathrm{t}$ & Confidenc & rrvals $95 \%$ & $\mathrm{R}^{2}$ & Adjusted $\mathrm{R}^{2}$ \\
\hline Book value * & -2.850 & 1.028 & -2.770 & 0.032 & -5.366 & -0.334 & \multirow[t]{7}{*}{0.963} & \multirow[t]{7}{*}{0.918} \\
\hline Dividend per share * & 5.959 & 2.071 & 2.880 & 0.028 & 0.891 & 11.026 & & \\
\hline Dividend yield & -21.880 & 21.361 & -1.020 & 0.345 & -74.148 & 30.389 & & \\
\hline Price earnings & 0.000 & 0.002 & -0.140 & 0.892 & -0.004 & 0.004 & & \\
\hline Earnings per share $* * *$ & 8.232 & 0.728 & 11.310 & 0.000 & 6.450 & 10.013 & & \\
\hline ROE & -5.487 & 4.245 & -1.290 & 0.244 & -15.874 & 4.899 & & \\
\hline Constant & 9.373 & 1.436 & 6.530 & 0.001 & 5.859 & 12.886 & & \\
\hline $\mathrm{F}$ & 105833.240 & \multicolumn{5}{|c|}{$0.000 * * *$} & & \\
\hline sigma_u & 10.653 & & & & & & & \\
\hline sigma_e & 3.097 & & & & & & & \\
\hline rho & 0.922 & ** significant at $5 \%$ & $* * *$ signi & nt at $1 \%$ & & & & \\
\hline
\end{tabular}


It is exhibited in Table 7 that the variables book dividend per share and earnings had a positive relationship with the dependent variable, while the other had a negative one. Focusing on significance, book value and dividend per share were significant at $5 \%$; while earning per share was significant at $1 \%$. Hence, dividend per share and earnings per share had a positive and significant relationship with the share price, while book value had a negative and significant relationship with the dependent variable. The coefficient of determination was .963 and its adjusted one of .918. Then it is possible to claim that selected regressors were able to explain about $96.3 \%$ of the effects of the dependent variable. Finally, the obtained $\mathrm{F}$ value, in Table 7 , was 105833.240 with a p-value of .000 ; hence, it is possible to claim the model is acceptable as all coefficients are different from zero.

\section{Discussion}

The research found that book value had a negative and significant relationship with share price. This finding is not consistent with none of the previous studies. Sharif et al. (2015) in the Bahrein stock market found a positive and significant relationship. Also Ozlen (2014) found a positive and significant relationship in all sectors analyzed even in the ones related to the metallic industry. Moreover, Hanifah (2019) found a positive and significant relationship of book value in the Indonesian telecommunication sector. Dividend per share was found to have a positive and significant relationship with share price. This finding is consistent with the one Sharif et al. (2015) and the research in banks made by Kembaren et al. (2019). Related to this, dividend yield also had a positive but no significant relationship with the dependent variable; such finding was not consistent with one of Sharif et al. (2015). Price earnings had a negative and non-significant relationship with market share prices. This finding is only consistent with the results of Hanifah (2019) and Ozlen (2014) in certain industries. Ozlen (2014) found a similar result in metal related industries and electric ones. The findings of Sharif et al. (2015), and Tambuati et al. (2017) found a positive and significant relationship. Here, Ozlen (2014) found a positive and significant relationship in paper, stone and textile industries; and a significant negative relationship in the industries of communication. Furthermore, it was found that earnings per share had a positive and significant relationship. This result is partially consistent with the research of Sharif et al. (2015) since they found a positive but not significant relationship. On the other hand, Hanifah (2019) found that earnings per share had a negative and non-significant relationship with Indonesian telecommunication companies. Also, Duy et al. (2017) found that earnings per share had a positive but not significant relationship with the stock prices of Vietnam. Finally, ROE had a negative but not significant relationship with the share prices. This result is consistent with the findings of Ligocká \& Stavárek (2019) since they found a similar result for Swiss food companies. However, in the same research it was found that for Polish companies' roe had a positive and significant relationship and in Austrian companies such relationship was negative and significant.

\section{Conclusions}

This research analyzed the relationship between financial factors and share prices in mining copper companies from 2010 to 2018. The research focused only in common shares with voting rights. Regressors were book value of shares, dividend per share, dividend yield, price earnings, earnings per share and ROE. Fixed effects were harnessed after testing for stationary behavior, distribution, and specification. It was found that book value had a negative and significant relationship with share price. This finding could be related to a minor confidence of investors since a capital restructure may erode shareholders' expectations.

Dividend per share had a positive and significant relationship with the dependent variable. Then, there is evidence for claiming that dividend payment increases share prices in the stock market, hence dividend payments make more attractive shares. In the case of dividend yield, even though it is related to dividend per share, the research found a negative but not significant relationship to share prices. Therefore, there is not enough evidence to state that dividend yield had a negative impact on share prices. Similar phenomenon happened with price earnings since it is related with earnings per share. The research found that earnings per share had a positive and significant relationship with share prices, while price earnings had a negative and nonsignificant one. In the study carried by Sharif et al. (2015) earnings per share had a negative relationship with share prices while price earnings had a positive and significant one. Also, it is interesting to add that in the study carried by Ozlen (2014) metal related companies price earnings also had a negative and non-significant relationship with their share price. Hence it seems that dividend per share with dividend yield, and earnings per share and price earnings although are related may go into opposite directions. Finally, it is necessary to remind that net income is an important component of earning per share ratio as issued shares; hence, it could be stated that companies' shares become more attractive as long as it increases its net income in a major proportion than the number of issued shares.

\section{References}

Del Águila, P., Martinez, M., \& Regalado, F. A. (2017). Cobre: Evolución reciente y potencial de desarrollo. Revista Moneda, $171,29-32$.

Alejo, J., Galvao, A., Montes-Rojas, G., \& Sosa-Escudero, W. (2015). Tests for normality in linear panel-data models. The Stata Journal, 15(3), 822-832.

Asadi, A. (2013). Examining the relationship between the dividend policy and stock prices in companies listed on Tehran Stock 
Exchange. Research Journal of Applied Sciences, Engineering and Technology, 6(22), 4186-91. https://doi.org/10.19026/rjaset.6.3530.

Banco Central de Reserva del Perú. n.d. "BCRP Data."

Baumohl, E., \& Lyocsa, S. (2009). Stationarity of time series and the problem of spurious regression. Available at SSRN 1480682.

Becket, M. (2017). How the Stock Market Works : A Beginner's Guide to Investment. Sixth. New York: Kogan Page Ltd.

Bolsa de Valores de Lima. (2018). Informe Bursatil. Lima.

Cámara de Comercio de Lima. (2019). Informe Ecoómico. La Cámara, 2019.

Congreso de la República del Perú. (1998). Ley General de Sociedades.

. 2011. Ley 29720. Diario Oficial El Peruano. Vol. 28. Lima.

Croux, C., Dhaene, G., \& Hoorelbeke, D. (2003). Robust standard errors for robust estimators. Katholieke Universiteit Leuven, Working Paper.

DeBenedictis, L., \& Giles, D. (1998). Robust specification testing in regression: The FRESET test and autocorrelated disturbances. Journal of Quantitative Economics, 15(1), 67-76.

Duy, V. Q., \& Dang, N. H. (2017). Determinants of stock prices of joint-stock companies in industrial sector listed on Hcm City Stock Exchange. International Journal of Advanced Engineering Research and Science, 4(4), 237124.

Fonti, V. (2017). Feature selection using LASSO. VU Amsterdam, 1-26. https://doi.org/10.1109/ACCESS.2017.2696365.

Fundación Chile (2018). Fuerza Laboral Minería Del Perú.

Galvao, A. F., Montes-Rojas, G., Sosa-Escudero, W., \& Wang, L. (2013). Tests for skewness and kurtosis in the one-way error component model. Journal of Multivariate Analysis, 122, 35-52..

Hanifah, A. (2019). The effect of earning per share (EPS), price earning ratio (PER) and price book value (PBV) against the stock price of telecommunications sector company included in the Indonesian Islamic Stock Index (ISSI). KnE Social Sciences, 711-726.

International Council on Mining and Metals. (2011). Sustainable Development and the Global Copper Supply Chain: International Research Team Report. no. June: 86.

Jaramillo, F. (2010). Valoración de Empresas. 1st ed. Bogotá: Ecoe Ediciones.

Kembaren, T., Achsani, N. A., \& Maulana, T. N. A. (2019). Dividend payouts, internal and other external factors, and its impact on stock price. Jurnal Keuangan Dan Perbankan, 23(2), 235-245.

Ligocká, M., \& Stavárek, D. (2019). The relationship between financial ratios and the stock prices of selected European food companies listed on stock exchanges. Acta Universitatis Agriculturae et Silviculturae Mendelianae Brunensis, 67(1), 299307. https://doi.org/10.11118/actaun201967010299.

Mahapatra, R. P., \& Biswasroy, P.K. (2011). Impact of fundamental and technical factors on the prices of equity shares in India : An econometric analysis. Finance India, 25(4), 1259-72.

Ministerio de Energia y Minas. 2019. Boletín Estadístico Minero. Lima.

Ozlen, S. (2014). The effect of company fundamental on stock values. Journal of Chemical Information and Modeling, 71(3), 595-602. https://doi.org/10.1017/CBO9781107415324.004.

PwC. (2019). Mine 2019 Resourcing the Future. Melbourne.

Romero, E., \& Contreras, C. (2006). Historia económica del Perú. Unmsm.

Sharif, T., Purohit, H., \& Pillai, R. (2015). Analysis of factors affecting share prices: The case of Bahrain stock exchange. International Journal of Economics and Finance, 7(3), 207-216.

Sherman, E. (2015). A Manager's Guide to Financial Analysis. 6th ed. American Management Association.

Stock, J. H., \& Watson, M.W. (2008). Heteroskedasticity-robust standard errors for fixed effects panel data regression. Econometrica, 76(1), 155-74. https://doi.org/10.1111/j.0012-9682.2008.00821.x.

Subing, H. J. T., \& Kusumah, R. W. R. (2017). An empirical analysis of internal and external factors of stock pricing: Evidence from Indonesia. Problems and Perspectives in Management, 15(4), 178-87. https://doi.org/10.21511/ppm.15(4-1).2017.02.

Vázquez, X. E. C., \& Miranda, G. J. (2019). Relación entre indicadores económicos y precio de acciones en empresas brasileñas. Revista Facultad de Ciencias Económicas, 27(2), 51-66.

Wooldrige, J. (2010). Econometric Analysus of Cross Sectin and Panel Data. Second. Cambridge: The MIT Press.

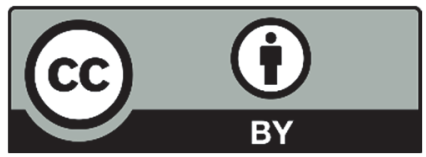

(C) 2021 by the authors; licensee Growing Science, Canada. This is an open access article distributed under the terms and conditions of the Creative Commons Attribution (CC-BY) license (http://creativecommons.org/licenses/by/4.0/). 